\title{
Solving the Ecological Problem Using Systematic Guarantee Measure
}

\author{
Xinsheng Yu, Lingxia Jin \\ College of Marxism \\ East China University of Technology (ECUT) \\ NanChang, China \\ 524725612@qq.com,1013594678@qq.com
}

\begin{abstract}
-ecological problem is the common challenge facing the world. Ecological problem naturally reflected the unequal relationship between man and man. Why the ecological problem defies solution is because of the commonality and integrity of ecosystem. So how can we solve ecological problems,it is crucial to attention people in systematic contact with nature. However the public ownership gives people right to equal occupy the ecological resources, and the exclusion of capital accounts result in the ecological resource possession, this is the system safeguard to ecological problem. The transformation of socialist government's ecological functions provide the guarantee for overcome the external uneconomic behavior, the understanding and observing the law of ecology provide the conditional guarantee to ecological problem.
\end{abstract}

Keywords—ecological problem; systematicness; social public ownership

Ecological crisis is a big problem, it will threat the development of human. At the same time, also bring out a serious pollution problem of the acoustics environment. And along with people's consciousness on the environment. Now two mentality about ecological crisis in theorists: the first one about human and nature, ecological crisis is natural punishment because of destruction of nature by human being, so they thought repair the relationship of human and nature by competition to save resources, it is not to change the social system. The radical views do emphasize the intrinsic value of nature and the modernity of consumption. The second one is about the relationship of human. It is the struggle of man and man do bring about ecological crisis. So this vies suggest to wipe out private ownership to change the ecological crisis by system.[1](p36) These views both moral and immoral, it separate nature from human beings, it do not put people and nature in one systematic view of the world, it is hard to be imitated by developing countries. So where is the puzzle of ecological problems? Can it be solved? How to resolve? This paper survey ecological crisis to systems theory, and recommend resolution.

\section{THE DESTRUCTION OF NATURAL SYSTEM BY} CAPITAL LOGIC IS THE MAIN SOURCE OF ECOLOGICAL PROBLEMS

Capital's mad pursuit of profits is the root cause of natural systemic destruction. Ecological problems are arise from people's wrong view of nature. The existence and development of human depend on the natural environments, nature provides nourishment and habitat for human. There is no individual or group can completely escaped the nature to existence. Man comes from nature but different from nature. Man must act on nature to obtain survival information, nature becomes an object and a means for human. Since modern times, people have regarded nature as the object of conquest and nature is the antithesis of existence. Amir Khadir said animals are machines, Animals should be used in accordance with the method of separation from nature. In Hegel's natural philosophy, nature becomes the object of spiritual externalization, It is the spirit that unfolds and returns to itself. Only by virtue of the emotional objects of reality people can express their abilities and talents. In the logic of capital, people are more likely to see the exchange value of nature itself, and neglect the ecological value or other value of nature. To this day, 
people still uphold the concept of conquering nature, this becomes the ideological root of the formation of ecological problems.

Second, the main source of ecological problems is the unlimited expansion of natural. In transforming natural production practices, people do it through capital. In order to produce more products, people are divisions and corporations and exchange distribution and consumption through certain organizational forms. But capitalists are not satisfied with producing products to meet their own consumption, more is the expansion of production and the pursuit of excess profits. Especially since the beginnings of the Industrial Revolution, with the development of science and technology, machine-oriented production methods gradually dominate in market, so industrial production does not depend on nature but to conquer and master nature like the logic of capital. Industrial production is no longer satisfied with value-in-use of goods, and to pursue the abstract value of goods and exchange value with a view to making more profits. At present, the organic composition of capital is constantly improving. Capitalist are constantly explore new territory and occupy new resources, expand the sale market of goods to profit.[2](p108) The result of the capital globalization movement is that where does the capital go and the consumption of natural resources occurs, and where does the environmental pollution take place. Since capital expansion cannot stop, ecological pollution cannot stop. The current global ecological problem is essentially the result of the global exploitation of natural resources and irrational use of natural resources, It is the forcible conquest and deprivation of nature by capital worldwide.

Finally, the ecological problems are directly reflected in the unrestrained and unrestrained emission of pollutants, and capital expansion not only manifests itself in production, but also in its logic. According to the law of the outbreak of capitalist economic crisis, the average profit margin of capital will gradually decrease under the continuous improvement of capital, In order to gain more excess profits, the capitalist must improve the technology and use more advanced machines for production, which leads to a large surplus of capitalist production. In order to reduce the loss of product, capitalists adopt various means to induce consumption fashion and advocate material consumption. This kind of consumption is not reasonable consumption, but deformed consumption, it is to meet the consumption that people need in one aspect. People's consumption is not for their own better development, but to meet the needs of capital appreciation, this leads to excessive consumption of natural resources, In particular, the massive destruction and waste of non-renewable resources makes the sustainable development of nature unsustainable. Capitalists are not concerned about the emissions of pollutants when they make large-scale use of natural resources, resulting in a growing environmental problem. Marx reveals an insurmountable fundamental contradiction in capitalist society, namely the contradiction between the infinity of capital accumulation and expansion and the fortitude of natural resources. Capital does not change its greed, ecological problems can not be eliminated for a moment. The contradiction between the expansion of the capitalist mode of production and the limited production condition is the real source of ecological problems.

\section{THE SYSTEMIC AND HOLISTIC NATURE OF} ECOLOGICAL ENVIRONMENT CANNOT BE SOLVED BY SOCIAL DISTRIBUTION SYSTEM

The physical transformation of man and nature is a social structure, and the possession relation of production data is the core of social structure. Therefore, the relationship between man and nature cannot be separated from the possession of the production data. The root of ecological problems lies in the unequal possession and plunder of natural resources. There is a sharp contradiction between the private ownership of natural data and the integrity of ecosystem. Private ownership requires the separation of natural resources, which is not in accordance with natural and organic characteristics. The whole and systematicness of ecological environment is one of the fields. As a private society, it is impossible to solve ecological problems, because the ecological system is 
the whole, not the local, and is public rather than private. The systematic and public nature of the ecosystem itself is an important reason why the ecological problems are difficult to solve it.

First of all, the organic whole of the ecosystem is contradictory to the property rights of the private ownership itself. The capitalist society values individualism and private ownership. Private ownership is an institutionalized regulation of the personal production data. Because private ownership is difficult to divide the ecological environment as a whole, this will produce a series of external behavior, that is, some behavior main body when engaged in an activity, the activity results affect others, to other agents or society as a whole has brought some degree of damage or benefit, but has not yet pay fee or get corresponding remuneration. The externality of ecological environment shows that good ecological environment plays a good role in promoting the development of individuals or enterprises. The dirty and messy environment can bring negative externalities to individuals or enterprises, thus causing harm to individuals or enterprises. Due to the ecological environment is different from general public characteristics of products, individual or enterprise generally use good ecology brings positive externalities, in this case, the good ecological environment is unsustainable.

Secondly, there is a contradiction between the spread of environmental pollution and the long-term impact of environmental pollution. The formation of ecological problems is not formed overnight. As a whole natural environment, the damage is directly related to the western industrial revolution. In the 17th and 8th centuries, western countries had already discharged waste water and waste from the natural world, but at that time, there was no corresponding attention on it. The environmental pollution caused by Britain's industrial revolution is still fresh. After that, the western countries carried out large-scale industrial revolution, which caused the environmental pollution directly to the present, so that the whole world paid for it. Now, in terms of pollution control, western countries tend to take historical responsibility for a variety of reasons. At present, developed countries have abundant capital and advanced technology, and have the ability to deal with environmental problems. Developing countries are under pressure to continue to discharge waste gas and waste water from the natural world in order to develop the economy, thus causing ecological continuous pollution and continuous destruction.

Finally, the historical continuity and technology of ecosystem are contradictory to the time-space transcendence of natural resources utilization.The natural system is a self-organizing system. The exchange of material and energy between human society and nature is of certain coordination and balance. The energy distribution and material exchange of various elements within the natural system is regularity. However, at present, the development of technology constantly breaks through the space and time limits of natural resources, so that the resources formed in hundreds of millions of years can be used up in a short period of time, thus forming the strong control of capital on nature. In order to achieve profit growth, they also continuously change the inherent law of the existence of biology, shorten its life cycle. By changing the growth genes of food through technology, creating new species and expanding the variety of goods; the technology constantly accelerates the reproduction frequency of creatures, making instant products and so on.

At present, some scholars, when analyzing ecological problems, often confine the formation of ecological problems to the contradiction between man and nature, and ignore the effect of specific social system on nature. In fact, the exploitation and utilization of natural resources are carried out in a certain way of human organization. People in certain production relationships organize natural resources to exchange and allocate and consume natural resources. But under the private system, people do not produce consumption according to reasonable needs, but make consumption in pursuit of profit. Natural resources are not a means of serving the whole population, but a means for capitalists to plunder resources for profit. Before the capitalist production relations, because of low productivity, people's ability to the development and utilization of natural resources is limited, therefore, 
there would be no cause major ecological problems appear, nature also can repair themselves successfully. But since the formation of capitalist mode of production, capital has established absolute dominance over natural resources, and natural resources are constantly being eroded and destroyed. The erosion and destruction of capital to natural resources is far beyond the self-repairing ability of nature. As the main carrier of capitalist mode of production Exchange distribution enterprises in the production and consumption in the process of constant pursuit of profit increment, the aesthetic value of natural resources Keeping in good health function has not been completely. Some scholars believe that natural resources can be adjust by the market, to reduce costs, save resources, but if you don't change the capital nature of the infinite pursuit of profit, per unit product energy saving will eventually lead to natural resources by an increase in the number of the total amount of increase, this how to save resources.

\section{THE TRANSFORMATION OF SOCIALIST PUBLIC OWNERSHIP AND GOVERNMENT FUNCTIONS PROVIDES THE POSSIBILITY FOR SOLVING ECOLOGICAL PROBLEMS}

The profound impact of ecological problems has to be taken seriously. It is because nature itself has the public nature that it not only threatens the victims of environmental problems, but also threatens the environmental problems, so that today people are all concerned about ecological problems. It is because nature itself has the public nature that it not only threatens the victims of environmental problems, but also threatens the environmental problems, so that today people are all concerned about ecological problems.

\section{A.The socialist public system pay attention to the} systematicness, it provides institutional guarantee for restoration of ecosystem

Ecological problem is the root of the interpersonal relationship is not harmonious, people should pay attention to the whole and fate and interest is the starting point to solve the problem of ecological community, therefore, must solve ecological problems from the change of production relation of people unfair. However, some western scholars advocate to solve the problem of ecological pollution from technology, and advocate the use of artificial ecosystem to replace the natural ecosystem to meet the continuous demand of people. Admittedly, technology is a way to solve ecological problems. Without technical support, enterprises may pollute more seriously but technology is still subject to the value orientation of the system. The technology is in a certain production relationship and is bound by all systems. It is possible to be used by others without a good system environment, and there are still some risks and ethical disputes. Under the capitalist system, the motive force of technology serves the fundamental goal of increasing profits. Only under the public ownership, technology can serve the masses, so that the masses can become victims of the ecological crisis. The value of technology should be reflected in its aim not at the value-added of profits but in the common well-being of all the people. The socialist public ownership decides the technology to serve the people, and the pursuit of efficiency should also take into consideration the physical and mental health and natural capacity of the laborer, and not only consider the increasing marginal benefit of the product. Therefore, the transformation of the concept of development, emphasizing the people-oriented development concept, appears particularly prominent.

Socialist public ownership can realize public ownership of natural resources and give play to the leading role of public ownership in ecological protection. Private ownership of capital protection until the indulgence, the greed of capital is not restricted by the system. On the contrary, in some ways, the private system gives the greatest protection to the greed of capital. To be sure, development production cannot leave capital, capital brings economic prosperity and technological progress, capital brings employment opportunity life convenience. But with the greed of capital, environmental disasters have followed. In order to chase the best interests, the capital puts the health of the public in disregard of the destruction of the natural 
environment. There is a direct or indirect link between the depletion of the ozone layer and the expansion of acid rain in the ozone layer. And public ownership has realized the equal relationship of ecological resources possession, ruled out the individual with the possession of capital free possession of the possibility of ecological resources, for the realization of the public environment interest and the system of environmental protection priority to lay a good foundation, so it is the basis to solve the problem of ecological. Public ownership can control the greed of capital. It can make overall consideration, and regulate the utilization of production materials or natural resources according to people's reasonable needs. Public system for people's all-round development as the goal, was based on reasonable person's demand to meet, to the human and the nature harmonious development of people to return, limiting luxury consumption and curb unreasonable demand, so as to promote the sustainable development of ecology, common prosperity and promote the social harmonious development between human beings. Public ownership can also overcome the negative impact of the market mechanism and give more attention to non-market sectors. For the public service sectors, such as the historical heritage of the ecological region, the market cannot get rid of or eliminate the influence of the external environment. This requires active attention and action from countries or governments that represent the interests of the whole. In order to the interests of the whole society, governments should regulate the direction of the capital, restrict capital into the polluting enterprises, constraints on capital spending on luxury products, limit the rich to the excessive consumption of luxury goods, for some of non-renewable resources ration. Resources bearing capacity at the national level, the requirement for the ceiling, the polluting enterprises adopted a policy of reversed transmission, an unspecified number of excess production capacity, through tax fiscal policy lever to promote enterprise transformation, low carbon economy development of circular economy, prompting higher energy utilization efficiency and energy structure rationalization and clean. At the same time, national policies, increase the ecological infrastructure of inputs such as public health, health education, to gradually reduce the unfair of society, reduce the effects of the ecological crisis to vulnerable groups.

B.The ecological transformation of the functions of socialist government overcomes the negative externalities and provides an organizational guarantee for the realization of the integrity of the ecosystem

To solve ecological problems, we must consider the public property of the ecological environment to overcome the external non-economic phenomena. Due to the integrity of the ecosystem and ecological civilization construction of a glorious all glory, broken phenomenon, make the ecological environment construction also become a complicated system engineering for a long time, it needs to solve the coordination of resources protection and development and utilization, need to adjust the balance of economic construction with resources and environment, between different regions should be well dealt with different interest relations between industry groups. Otherwise, there will be a loss and loss in terms of dealing with the standard aspects, which should reflect the relationship between diachronic and realtime and actuality, both to the right of duty and to the distinction of treatment. Because of ecosystem integrity and characteristics of the public and to solve ecological problems, must want to have a coordination organization as a whole was arranged, need a strong economies of government organization and coordination. Preventing some people from taking advantage of an external good environment, while others do not get paid for it; Preventing some vested interests in order to pursue their own interests, and the ecological cost and ecological risk on to social or other group, they have made the corresponding economic interests, did not bear shall pay for the cost; Preventing the current generation from destroying the ecology, the next generation will bear the consequences. Therefore, the socialist government as a representative of public interests, it can be used as a unified organizers and coordinate the implementation of ecological management and supervision functions, can be the protection of the public resources and benefit-sharing, 
can from the national game, limiting urban-rural pollution transfer, constraint the rich improper consumption behavior, etc. Currently some of the vulnerable groups, they are the victims of the ecological destruction, is the ecological cost and ecological risk takers, but can't get the benefits of economic growth and enjoy the benefits of ecological resources, need more government organization as super economy give corresponding funds or subsidies, realize ecological justice. And the socialist government has this advantage to focus on doing great things and doing good things.

There is no rejection of the role of the market mechanism. The government can use the market mechanism to protect the ecology effectively. In the field of competitive resources, the design of the property rights system should be strengthened to clearly define the ecological responsibility of all people. Government can introduce price mechanism, through means such as tax and fines, increase the production cost of enterprises, so as to further encourage enterprises to save energy, strengthen management, reduce pollution.

In terms of organization and operation, it can give full play to the advantages of democracy and create a platform to encourage the public to actively participate in ecological protection. The complexity and integrity of the environmental system determines that ecological protection cannot be a person's behavior, but requires public participation. Although the government's role in promoting the development of social and environmental protection should not be underestimated, the government's unilateral strength is limited and to let the public to actively participate in environmental protection work, and promote the benign development of the social environment protection, achieve finally everyone to participate in the ecological construction Everyone Shared ecological protection responsibility Everyone is sharing the benefits of the ecological environment. The government should build a platform for the masses to participate in ecological protection, and provide institutional support for the public to expose the pollution behaviors and provide a platform for the public to enjoy the benefits of the environment. To encourage public participation, the government has the right to participate in the protection of environmental resources and to share the benefits of natural resources. In terms of institutional norms, citizens are entitled to the right to participate in the right to know, and to participate in environmental decision-making and environmental management. The public system of socialism determines that the government's service function can do this, because it aims at the interests of the general public and does not have its own interests.

C.According to the objective law of natural development, the unity of human initiative and objective regularity is the basic condition to solve the ecological crisis

Dialectical materialism tells people that the subjective initiative of people must be the premise of recognizing the objectivity of the law. Environmental protection requires active action, but it must respect the laws of nature. Any subjective effort to disregard ecological rules will only make matters worse. China has realized the socialist public system in 1956. However, due to the lack of understanding of ecological laws at that time, the action to destroy the ecological environment, such as the land reclamation and land reclamation, was still affected. Respecting the natural law is to respect biological diversity, respect the laws of natural growth, and protect the sustainable nature of natural resources, develop and utilize within the natural tolerable range, etc.

At present, it is very important to increase the education of reasonable consumption of citizens. The broad masses of education set up the concept of resource limited rational consumption and make the consumption way ecological. In terms of lifestyle, we should change traditional consumption patterns and establish healthy consumption patterns. Due to the influence of profit, the unreasonable demand of people is greatly exaggerated by the media, and the social life has also appeared the bad atmosphere of hedonistic conspicuous consumption and the pursuit of luxury. We should advocate moderate consumption way of life and the establishment of green consumption, the frugal way of life, reduce the unreasonable material consumption, the pursuit of quality of life more toward 
spiritual life. From an early age, we have been frugal and wasteful and wasteful and wasteful. We have made ecological protection from our daily life. Only when people are able to set up a limited resource from the inside of their hearts, people will have greater interests and a better environment in order to protect the environment from actual actions. In a word, efforts should be made to realize ecological development and economic and political social and cultural development, and to combine the development of nature with the protection of nature, we should be respectful to nature. The difference between the right to live and the right to development is combined with common development. The coastal regions and the central and western regions can only truly solve the environmental problems in combination with the pooling of interests and interests in the resource utilization.

\section{References}

[1]liushengren, "The actuality of green capitalism and its limitations”, Compilation of conference papers of the Chinese socialist ecological civilization research group, p36, 2005.

[2]PepperDavid, “Eco-socialism:From Deep Ecology to Social justice”, jinan, shangdong university press, p108, 2012. 